\title{
Investigating Ownership Structure, Company Characteristics and Online Environmental Disclosure in Malaysia
}

\author{
Ali Saleh Ahmed Al_arussi ${ }^{* 1}$ and Redhwan Ahmed Al_dhamari ${ }^{2}$ \\ ${ }^{1}$ Xiamen University Malaysia \\ 2 Tunku Puteri Intan Safinaz School of Accountancy, Universiti Utara Malaysia
}

\begin{abstract}
This paper focuses on environmental disclosure on the Internet and empirically examines whether ownership structure and company characteristics have a significant association with the level of Internet environmental disclosure (IED) amongst Malaysian companies. Six variables - management ownership, government ownership, firm size, level of technology, industry type, and profitability - have been chosen to be examined in this study. Multiple regression analysis is used to examine these relationships by analysing the data of 201 online annual reports on the websites of Malaysian companies. The results indicate that government ownership, firm size, level of technology and industry type are positively and significantly associated with IED; management ownership is negatively and significantly associated with IED, and profitability did not show a significant relationship. The results of this paper can be used by regulators to enhance and regulate online environmental reports as it is still voluntary based.
\end{abstract}

Keywords: Ownership Structure, Company Characteristics, Online Environmental Disclosure, Environment, Malaysia

JEL Classification: M41

Paper Type: Research

\section{INTRODUCTION}

Companies face different types of pressure to report their environmental information, and such pressures are increasing especially after global environmental problems. These pressures are climate change, acid rain, high temperatures or global warming, water

*Corresponding author: E-mail: al_arussi@yahoo.com 
pollution and ozone layer damage (Yearley, 1996; Frank et al., 2000; Eccles \& Krzus, 2010). Dunlap and Scarce (1991) surveyed public opinion regarding environmental issues and stated that the public views corporations and industry (in general) as significant contributors to environmental problems. Accordingly, people are attempting to avoid buying products from corporations that have poor environmental records.

Previous studies determine a number of reasons that motivate companies to disclose their environmental reports, such as marketing companies' products and services (Solomon \& Lewis, 2002), to reduce cost of capital (Dhaliwal et al., 2011), and to gain a competitive advantage (Cheah et al., 2007). However, most corporations in developed and developing countries disclose their social and environmental reports to enhance their reputation in the eyes of interested users (Amran \& Devi, 2008; Rettab et al., 2009; Rahul, 2010).

Similarly, individual investors see environmental information as being more attractive than other social activity information (Epstein \& Freedman, 1994). In addition, stakeholders and other interested parties make a connection between environmental performance and economic performance in corporations. This connection is supported by Al-Tuwaijri et al. (2003) who found a significant association between environmental performance and economic performance. Consequently, corporations are required to disclose their environmental information in their annual reports (Walden \& Schwartz, 1997), and since printing the annual report is costly and has limited space, using the Internet to disclose corporation information is an efficient alternative, as it enables companies to capitalize on the benefits of Internet technology, such as unlimited space, low cost (Botosan, 1997; Angskun \& Angskun, 2008), extensive coverage (Adham \& Ahmed, 2005), timely and up-to-date information (Joshi \& Al-Modhahki, 2003), and it supports powerful hypertext and hypermedia presentations (Xiao et al., 2005).

Malaysia is an emerging market country that has taken considerable strides in corporate social responsibility (CSR). The latest announcement was made at the beginning of 2007, which requires all listed companies on the Malaysian stock exchange to disclose their CSR activities (which includes economic, social and environmental activities) in their annual reports (Bursa Malaysia, 2011). However, this latest regulation does not apply to online reporting. Based on the Internet Live Statistics Report1, the growth of Internet users in Malaysia was $16 \%$ in 2014, which, although high in comparison to other Asian countries. However, the number of companies that have websites and disclose their information including environmental information is low (Hassan et al., 1999; Healy \& Palepu, 2001; Nik Ahmad \& Sulaiman, 2004: Al_arussi et al., 2009, Mamat et al., 2013).

Also, a few online environmental studies have been conducted in Malaysia; the results show that the level of online environmental disclosure is still low and does not exceed $30 \%$ out of the target companies (Mokhtar \& Sulaiman, 2012; Al_arussi et al., 2013; Claudia et al., 2014). This leads to lower transparency amongst Malaysian companies (Leung et al., 2006; Wan Mohamad \& Sulong, 2010). Investors, customers and other interested users are looking to IED from different aspects based on their interests and concerns, but all agreed about the importance of such online reports (Lodhia, 2004). Hossain and Reaz (2007) argued that to enhance the level of environmental disclosure, it is essential to know the factors that affect managers' decisions regarding the disclosure issue and then use these factors to predict disclosure levels and enhance the quality of non-financial reports.

The ownership structure in Malaysian companies is one of concentrated ownership, in which most of the shares are commonly in the ownership of the state, families or individuals, and almost $73 \%$ of the shareholdings are owned by the top twenty shareholders (Abdullah \& Mohd-Nasir, 2004). A recent study stated that families hold around $44.7 \%$ of company shares (Carney \& Child, 2013), and between $15 \%$ to $80 \%$ of 
companies have managers who are family members and controlling owners (Claessens et al., 2000).

In addition, government-controlled institutions also hold significant shares in Malaysian listed companies, making the connection with companies more political than social (Mohd Ghazali \& Weetman, 2006), as this type of ownership structure leads to a reliable monitoring power over a company's managerial decisions including those concerning environmental disclosure (Abu Sufian \& Zahan, 2013).

In this context, this study concentrates on two types of ownership - management ownership and government ownership and examines their impact on the level of Internet Environmental Disclosure (IED). In other words, this paper empirically examines some factors that have been attributed to be company's characteristics, and that may influence the level of IED among Malaysian listed companies. These factors are management ownership, government ownership, firm size, level of technology, industry type, and profitability.

The remainder of this paper is structured as follows: Section 2 provides an overview of Internet reporting and reports on some studies on IED as well as presents the development of the hypotheses, while the research method and measurement of the variables are described in Section 3. Section 4 discusses the regression analysis results. Finally, Section 5 presents the conclusion of this paper and the recommendations for future research.

\section{LITERATURE REVIEW AND HYPOTHESES DEVELOPMENT}

The environmental report is defined as "The provision of financial and non-financial information relating to an organisation's interaction with its physical and social environment, as stated in corporate annual reports or separate social reports" (Guthrie and Mathews, 1985: 253). In other words, environmental reports represent a company's environmental performance in terms of the type of materials used and recycled; direct and indirect energy consumption; preservation of biodiversity life; water utilisation; reduction and treatment of emissions, effluents and waste; and decreasing the effects of the company's products and services on the environment (Global Reporting Initiatives, 2011).

Malaysia is behind other developing countries regarding the level of CSR (Chambers et al., 2003), and the environmental issues are poorly addressed (Bursa Malaysia, 2007; Thompson \& Zakaria, 2004). For this reason, Bursa Malaysia launched its CSR framework for public listed companies in 2006, and, subsequently, in 2007, it announced that all public listed companies are required to disclose CSR activities (including environmental activities) in their annual financial reports (Bursa Malaysia, 2011).

Few studies on environmental reporting have been conducted in Malaysia. Although, Teoh and Thong (1984) published a study, which included a survey of a combination of one hundred foreign and locally owned companies in Malaysia, the survey concentrated on three themes; namely, CSR concept, corporate involvement in such CSR activities and corporate social reporting. The results showed that only $29 \%$ of the selected companies reported their social performance in their annual report, and foreign-owned companies disclosed more CSR activities than local Malaysian companies.

Recent studies, such as Nik Ahmad and Sulaiman (2004) and Smith et al. (2007), and the later studies by Nik Ahmad and Mohamad (2014) and Sulaiman et al. (2014), focused on printed reporting. Internet reporting studies are even fewer; see for example Hassan et al. (2012); Homayoun et al. (2012); al_arussi et al. (2013); Mamat et al. (2013) and the latest study was conducted by Claudia et al. (2014). All the above studies either focus on the printed report or Internet reporting in general; this study focuses explicitly on online environmental reporting. 
The benefits of using the Internet as a means to disclose environmental information are the most common area of discussion in the IED area. Lodhia (2004) considered that such benefits as global reach, timelines, wide range of communication, updateability, flexibility in presenting the information, easy searching and navigating, low cost and integration were the most important benefits of online environmental reporting; however, the study discussed some limitations of online environmental reporting, such as information overload, costs of the installing report, digital divide, competence, online security problems, lack of authentication, lack of attestation and legal impediments, as well as poor website design, advertising and a variety of user preferences. Andrew (2003) stated that the Internet could enhance transparency with an opportunity to increase their environmental disclosure if the Internet is entirely utilised interactively.

A number of theories have been used to explain online reporting, such as the agency theory (Healy \& Palepu, 2001), signaling theory (Ahmed et al., 2003), stakeholder theory (Jones \& Wicks, 1999; Suttipun \& Stanton, 2012) and cost and benefit hypothesis (Al_arussi et al., 2009). However, the legitimacy theory is also a vital theory to consider; this theory presumes that companies have no right to exist if their values are not perceived as matching those of the society in which they operate (Dowling \& Pfeffer, 1975; Lindblom, 1994; Magness, 2006). Based on this presumption, companies should provide suitable information that builds a good image of their companies in respect of social interests and the minds of external users (Cormier \& Gordon, 2001).

Using the Internet as a media for companies to disclose their environmental reporting can be considered as a communication source to investors, social interests and other external users. In other words, legitimacy is presented in this type of disclosure. Thus, this study uses this theory as the underlying theory to explain the online environmental disclosure by Malaysian listed companies. Moreover, this study empirically examines the potential effect of some factors concerning the level of environmental disclosure on the Internet.

\subsection{Management Ownership}

Jensen (1993) stated that "many problems arise from the fact that neither managers nor non-manager board members typically own substantial fractions of their firm's equity" ( $p$ 864). The definition of Managerial ownership represents the percentage of ordinary shares that are held by management in the corporation, such as by the CEO or executive directors. A significant association has been found between management ownership and the extent of voluntary disclosure (Ruland et al., 1990). The agency cost theory interprets the above result as meaning that a lower percentage of management ownership discourages management to maximise shareholders' wealth, and, accordingly, shareholders demand more control and stricter monitoring mechanisms to supervise the behaviour of managers.

Conversely, managers have to reduce this fear and agency conflict and prefer to reduce information asymmetry by enhancing the level of voluntary disclosure. Eng and Mak (2003) found a negative and significant relationship between the level of voluntary disclosure and the percentage of management ownership when using the data for 158 companies listed on the Singapore Stock Exchange. In Malaysia, Mohd Ghazali (2007) examined the association between ownership structure and corporate social responsibility disclosure in the annual report, for which the results showed a negative and significant relationship. Halme and Huse (1997), and Nagar et al. (2003) supported the previous results and found that the higher the managerial ownership, the less inclined the managers are to divert resources away from value maximisation. 
In contrast, Uwuigbe (2011) found a positive association between managerial ownership and the level of corporate social responsibility disclosure after analysing the annual reports of 35 Nigerian firms for the period 2006-2010. He concluded that firms are willing to be environmentally friendly if they have a higher level of managerial ownership in their ownership structure as a way for managers to have a stake in the long-term survival of a firm, and, therefore, in enhancing the firm performance. This study takes a different path and empirically examines the relationship between the percentage of management ownership and the level of IED. Therefore, the first hypothesis is proposed as follows:

$\mathrm{H} 1$ : Management ownership is positively associated with the extent of environmental disclosure on the Internet by Malaysian companies.

\subsection{Government Ownership}

Government ownership is defined as the rule that pushes corporations to disclose more information (Eng and Mak, 2003). In terms of environmental reporting, the governmentlinked companies (GLCs) are a benchmark for other corporations due to the level of environmental activities and level of disclosure imposed by them. This is because the government is becoming more concerned about protecting people and the environment than mere profitability (Mak \& Li, 2001). Cheng and Courtenay (2006) argued that the existence of government ownership can enhance the level of voluntary disclosure as part of the state's commitment to transparency and corporate governance.

Cormier and Gordon (2001) stated that GLCs disclosed more social and environmental information than private companies did due to the social and political support. Both Tagesson et al. (2009), and Amran and Devi (2008) reported a positive relationship between government ownership and corporate social disclosure. The researchers considered this positive relationship to reflect the government's efforts to create a favorable image in the minds of users over time, and to obtain economic benefits from attracting international investors who give substantial consideration to this type of disclosure. This study intends to verify whether government ownership has a positive impact on the extent of online environmental reporting in Malaysian listed companies; therefore, the second hypothesis can be stated as follows:

$\mathrm{H} 2$ : Government ownership is positively associated with the extent of environmental disclosure on the Internet by Malaysian companies

\subsection{Firm size}

The earlier study by Izah (2003) stated that large companies are more in the eyes of society, and, hence, disclose their information to avoid speculative trading of their shares. Craven and Marston (1999) found a positive relationship between company size and the level of disclosure; this relationship, as interpreted by the agency theory, is because large companies are always in need of external funds due to their wide range of activities. This, in turn, increases the agency costs due to the conflict of interests among shareholders, managers and debt holders. To alleviate this conflict, companies increase the level of disclosure to reduce the information asymmetry and agency costs (Inchausti, 1997; Healy \& Palepu, 2001; Ho \& Wong, 2001).

Other studies reason that the level of disclosure by large companies is determined by their need to show their operational quality to build, and maintain a better public image and low political costs (Patten \& Trompeter, 2003; Lo, 2003). The positive accounting theory literature supports previous scenarios as political costs are greater for large companies (Watts \& Zimmerman, 1986). The study of Teoh et al. (2003) stated that large 
companies disclose environmental information to show society that they care about the environment.

The latest study, by Akrout and Othman (2013), examined the relationship between firm size and the extent of IED in Arab Middle Eastern and North African (MENA) companies; the results of the analysis showed a positive relationship. In contrast, Mamat et al. (2013), and Laswad et al. (2005) found no significant relationship between firm size and non-financial disclosure on the Internet. These mixed results encourage the authors to reexamine the impact of company size on IED. Although there are many ways to measure company size, this paper uses total assets as the basis for measuring the size of the company, as it has been used by previous studies (Branco \& Rodrigues, 2008; Hossain \& Reaz, 2007). Based on the above discussion, the third hypothesis is:

H3: Firm size is positively associated with the extent of environmental disclosure on the Internet by Malaysian companies

\subsection{Level of Technology}

Adams and Frost (2008) argued that the extent of IED represent the level of technology in an organisation. In other words, the existence of a department of technology in a corporation is favourable regarding Internet disclosure (Lodhai, 2004), as having a website requires more than just uploading the files onto the corporation's website. It involves other responsibilities, such as maintaining the website, updating information, and uploading different types of file - audio, video and interactive links - all of which are the responsibility of the technology department in the corporation.

A website, unlike paper-based reporting, has many appearances and formats, such as PDF, hyperlinks and others that require experts to operate them and ensure that the website is appropriately designed and that it provides the necessary information. If a company outsources these activities, using the Internet as a means for disclosure will be costly due to the fees levied for web setting and maintenance (Joshi \& Al-Modhahki, 2003; Lodhai, 2004). The cost and benefit hypothesis supports the above conclusion, and the existence of an information technology department is necessary to reduce such costs and to provide the desired information system.

This study attempts to study the relationship regarding the level of technology (existence of information technology department and the extent of IED. This variable is measured by using a dummy measurement ( 1 if the company has IT department and 0 if the company does not have IT department). Thus, the proposed hypothesis is as follows:

$\mathrm{H} 4$ : The level of technology is positively associated with the extent of environmental disclosure on the Internet by Malaysian companies

\subsection{Industry Type}

Based on previous studies, the type of industry is a critical factor that may affect the level of disclosure (Teoh et al., 2003). It is argued that industrial pressure could push companies to follow special rules and disclose additional information (Inchausti, 1997). In addition, companies in the same industry have to follow these rules, or it may negatively affect their reputation if they hide bad news (Craven \& Marston, 1999). This argument is supported by the institution theory.

Greenwood and Hinings (1996) argued that, based on the institutional perspective, organisations must achieve the institutional expectations to survive, even though such expectations may not lead to higher performance. Tariq (2001) also supported the above conclusion and found an association between industrial type and voluntary Internet disclosure. Hassan et al. (1999) found that only the decision to have a corporate website 
is affected by the type of industry when they examined the association between industrial type and Internet disclosure amongst Malaysian companies.

Other studies argued that the level of disclosure depends on whether companies are environmentally sensitive, which encourages them to disclose environmental information in their annual reports (Deegan \& Gordon, 1996; Banerjee, 2002; Suttipun \& Stanton, 2012). There are many ways to define the type of industry; earlier studies described the type of industry by using typical industries for some years. Others described the type of industry according to two main sections - manufacturing and non-manufacturing companies (Cooke, 1992; Lymer, 1997). This study prefers to include seven categories to define the industrial type variable; these categories are a consumer product, construction, industrial product, properties, plantation, technology, and trade and services. The researcher chose these seven categories because they represent the majority of Malaysian companies. Thus, based on the above discussion, the proposed hypothesis is as follows:

H5: There is a significant association between the type of industry and the extent of environmental disclosure on the Internet by Malaysian companies.

\subsection{Profitability}

Based on the signalling theory, the managers of companies with better performance than others like to differentiate themselves from other companies by disclosing more voluntary information, including environmental information (Ahmed et al., 2003). Zheng et al. (2009) examined the association between profitability and corporate social disclosure and found a positive relationship. In contrast, Mamat et al. (2013) found that profitability is not associated with the level of disclosure practices on the Internet. This paper examines whether the profitable companies in Malaysia are concerned about the environment. Thus, the proposed hypothesis is as follows:

H6: Profitability is associated with the extent of environmental disclosure on the

Internet by Malaysian companies.

\section{RESEARCH METHODOLOGY}

This study focuses on listed companies in Malaysia, as there have been few online environmental studies on countries in emerging markets. The sample size for this paper is 201 companies from seven non-financial sectors, which are considered to be the main contributors to environmental pollution in Malaysia (Salomone \& Galluccio, 2001). The data are secondary and were collected from company websites. An index of environmental disclosure is prepared and consists of 36 items that have been adopted from academically published papers.

A score sheet is prepared and utilised to score the level of environmental disclosure amongst the selected companies. In this study, the content analysis approach is used to fill up the score-sheet. This approach is used because content analysis has been proven by researchers to have excellent reliability; first, the coded data or set of data that they produce from the analysis is, in fact, reliable, and, second, the reliability is associated with the coding instruments (Milne \& Adler, 1999). Similar to previous studies, multiple regression analysis is utilised to analyse the data for this study (e.g. Camfferman \& Cooke, 2002; Gul \& Leung, 2004; Laswad et al., 2005).

The score sheet is marked one (1) if the item exists in the company's online annual report or website and zero (0) if the item does not exist. This way of scoring provides a fair judgment for the companies that carry out environmental activities in different areas and other companies that provide an extensive description of limited environmental activities 
in their reports. This is because the researchers are concerned about the variety and number of environmental activities rather than the number of words that are used for explanation.

The data were collected from surveying the annual reports on the websites of 201 companies for the year 2006; however, due to certain technical problems concerning some of the company websites, only 193 websites are fitted for further analysis, which presents $96 \%$. The data are analysed using the SPSS software analysis program. Multiple regression analysis is used to examine the relationships between management ownership, government ownership, firm size, level of technology, industry type, and profitability (as independent variables), and the extent of IED (as the dependent variable). In short, the general expression for Internet Environmental Disclosure in the form of a regression equation is as follows:

$\begin{array}{rlrl}\text { IED }= & a+\beta 1 \text { MANOWN }+\beta 2 \text { GOVOWN }+\beta 3 \mathrm{FS} \\ & +\beta 6 \mathrm{PROF}+\varepsilon & \\ \text { Which: } & a & =\text { constant } \\ \beta & =\text { regression coefficient } \\ \text { MANOWN } & =\text { Management Ownership } \\ \text { GOVERN } & =\text { Government Ownership } \\ \text { FSIZE } & =\text { Firm Size } \\ \text { LEVTEC } & =\text { Level of Technology } \\ \text { TYIND } & =\text { Type of Industry } \\ \text { PROF } & =\text { Profitability } \\ \varepsilon & =\text { error }\end{array}$

The regression coefficient $(\beta)$ indicates the effect of independent variables on Internet Environmental Disclosure. In other words, for each unit change of independent variable, there will be a change equal to the size of $\beta$ in Internet Environmental Disclosure.

\subsection{Descriptive Statistics}

The first analysis of the data is the descriptive analysis, which mostly represents frequency distributions, in other words, it represents the frequency of incidence of each score value. The skewness and kurtosis ratios are used to determine whether the dependent variable is normally distributed. Based on Sekaran (2000), these two ratios should be between +/2 for each variable to be considered as being normally distributed. Table I shows that the values of skewness and kurtosis of Internet Environmental Disclosure (dependent variable) are 1.1434 , and 0.778 , respectively, and that the standard errors are 0.175 and 0.347 , respectively. These results show that normality exists in IED (dependent variable), and thus multiple regression analysis can be applied for further analysis.

Table 1. Descriptive Statistics: Dependent variable

\begin{tabular}{llll}
\hline Statistics & IED* & Statistics & IED \\
\hline Mean & 1.2479 & Skewness & 1.1434 \\
Standard Deviation & 1.4340 & SE Skewness & 0.175 \\
SE Mean & 0.1029 & Kurtosis & 0.778 \\
Minimum & 0.00 & SE Kurtosis & 0.347 \\
Median & 1.000 & & \\
Maximum & 5.83 & & \\
\hline${ }^{*}$ Internet Environmental Disclosure Index & & &
\end{tabular}


To ensure that all articles published in the journal have a uniform appearance, authors must produce a PostScript or PDF document that meets the formatting specifications outlined here. The document will be used for both the hardcopy and electronic versions of the journal. Table 2 shows the mean and standard deviation for the continuous variables but not the dummy variables; the continuous variables in this study are three in number. It can be seen that the highest value for the mean (32.396) is for the management ownership variable, while the lowest mean value $(9.761)$ is for the profitability variable. Table 2 also shows the minimum and maximum values for each variable.

Table 2. Descriptive Statistics of Continuous Independent Variables

\begin{tabular}{lccccc}
\hline Variables & Mean & Median & Minimum & Maximum & Std. Deviation \\
\hline Management ownership (\%) & 32.396 & 34.467 & 0.00 & 94.37 & 23.662 \\
Company Size & 19.821 & 19.463 & 17.07 & 23.45 & 1.324 \\
Profitability (EPS) & 9.761 & 7.445 & -234.76 & 207.60 & 32.03 \\
\hline
\end{tabular}

\subsection{Correlation Analysis}

The correlation analysis is performed in two steps; the first step is to test the correlation between the independent variables with each other. These correlations are relevant for researchers to enhance their understanding of any causal relationship among the variables, and, eventually, improve their ability to expect other variables. Table 3 (a) represents the results of such correlation amongst the independent variables. The second step of the correlation analysis is to test the correlations between the independent variables and the dependent variable. Table 3(b) shows the results of this test of correlation; it can be seen that almost all the independent variables show significant correlations with IED at significant levels of 0.01 and 0.05 .

\section{ANALYSIS AND INTERPRETATION}

Table 4 shows the regression coefficient; the findings of the regression indicate that the model fits with the type of analysis used for this study. The $\mathrm{R}$ square shows that more than $50 \%$ of IED determinants are explained by the six studied factors. The adjusted $\mathrm{R}$ square is almost $48 \%$, which is very good. The following section explains the results of the regression analysis regarding the proposed hypotheses.

\subsection{Ownership Structure}

The ownership structure is the first group of independent variables and contains two variables, which are management ownership and government ownership. The results show the following:

\subsubsection{Management Ownership}

Table 4 shows a significant negative association between management ownership and Internet environmental disclosure; the $t$-value $(t=-2.953, P<0.01)$ indicates that a lower percentage of management ownership leads to higher Internet Environmental Disclosure. Hence, the alternative hypothesis is rejected. The result is consistent with previous studies that found that management ownership reduces the level of voluntary disclosure including environmental information (Ghazali, 2007; Nagar et al., 2003). 
Table 3(a). The Correlation between the Independent Variables

\begin{tabular}{|c|c|c|c|c|c|c|c|c|c|c|c|c|}
\hline IND.Vs & GOVERN & CONPRO & INDPRO & CONSTRUCT & TRD\&SRVS & TECH & PROPRT & PLNT & LEVTEC & MANOWN & PROF & FSIZE \\
\hline GOVOWN & 1 & -0.037 & $-0.151^{*}$ & -0.031 & 0.096 & -0.064 & 0.093 & $0.171^{\star *}$ & $0.215^{\star *}$ & $-0.455^{\star *}$ & $0.135^{*}$ & $0.411^{* *}$ \\
\hline CONPRO & & 1 & $-0.327^{* *}$ & $-0.124^{*}$ & $-0.264^{* *}$ & -0.082 & $-0.156^{*}$ & -0.096 & -0.071 & 0.085 & $0.151^{*}$ & $-0.140^{*}$ \\
\hline INDPRO & & & 1 & $-0.190^{* *}$ & $-0.407^{* *}$ & $-0.127^{*}$ & $-0.241^{* *}$ & $-0.147^{*}$ & -0.092 & $0.200^{* *}$ & $-0.144^{*}$ & $-0.216^{*}$ \\
\hline CONSTRUCT & & & & 1 & $-0.154^{*}$ & -0.048 & -0.091 & -0.056 & 0.011 & -0.004 & -0.033 & 0.007 \\
\hline TRD\&SRVS & & & & & 1 & -0.102 & $-0.194^{* *}$ & $-0.119^{*}$ & $0.171^{* *}$ & $-0.235^{\star *}$ & 0.010 & $0.193^{* *}$ \\
\hline TECH & & & & & & 1 & -0.061 & -0.037 & $0.173^{* *}$ & 0.004 & -0.047 & -0.031 \\
\hline PROPERTY & & & & & & & 1 & -0.070 & $-0.148^{*}$ & -0.007 & -0.018 & 0.084 \\
\hline PLNT & & & & & & & & 1 & 0.044 & -0.115 & $0.142^{*}$ & $0.250^{* *}$ \\
\hline LEVTEC & & & & & & & & & 1 & -0.207 & $0.237^{* *}$ & $0.344^{* *}$ \\
\hline MANOWN & & & & & & & & & & 1 & -0.099 & $-0.324^{*}$ \\
\hline $\begin{array}{l}\text { PROF } \\
\text { F.SIZE }\end{array}$ & & & & & & & & & & & 1 & $\begin{array}{c}0.351^{* *} \\
1\end{array}$ \\
\hline
\end{tabular}

${ }^{* *}$ Correlation is Significant at the 0.01 level (2-tailed)

Table 3(b). The Correlation between IVs and DVs

\begin{tabular}{lll}
\hline \multicolumn{2}{c}{ Table 3(b). The Correlation between IVs and DVs } \\
\cline { 2 - 3 } & \multicolumn{2}{c}{$\begin{array}{c}\text { Correlation Coefficient } \\
\text { With }\end{array}$} \\
\cline { 2 - 3 } & Environmental (DV) & $\begin{array}{l}\text { Environmental } \\
\text { (DV) }\end{array}$ \\
\hline MANOWN & $-0.396^{* *}$ & The very low relationship at the significant level \\
LEVERN & $0.434^{* *}$ & Moderate correlation with a substantial relationship \\
INDPRO & $0.409^{* *}$ & Moderate correlation with a substantial relationship \\
PLNT & $0.119^{* *}$ & Very low relationship and not significant \\
PROF & $0.283^{* *}$ & Low correlation with the definite but small relationship \\
FSIZE & $0.329^{* *}$ & Low correlation with the definite but small relationship \\
$* *$ Correlation is significant at the 0.01 level $(2$-tailed) & Moderate correlation with a substantial relationship \\
\hline
\end{tabular}

* Correlation is significant at the 0.05 level (2-tailed) 
This result supports the agency theory, as management with lower ownership increases the level of online disclosure, as well as the legitimacy theory, as the type of online information disclosed is environmental information to legitimise the operations of their companies.

Table 4. The regression Coefficient between IVs and DV

\begin{tabular}{|c|c|c|c|c|c|c|c|c|}
\hline \multirow[t]{2}{*}{ Model } & \multicolumn{2}{|c|}{$\begin{array}{c}\text { Unstandardized } \\
\text { Coefficients }\end{array}$} & \multirow{2}{*}{$\begin{array}{c}\begin{array}{c}\text { Standardized } \\
\text { Coefficients }\end{array} \\
\text { Beta } \\
\end{array}$} & \multirow[t]{2}{*}{$\mathbf{t}$} & \multirow[t]{2}{*}{ Sig. } & \multicolumn{3}{|c|}{ Correlations } \\
\hline & B & Std. Error & & & & Zero-order & Partial & Part \\
\hline 1 (Constant) & -6.718 & 1.429 & & -4.702 & .000 & & & \\
\hline $\begin{array}{l}\text { FIRM SIZE } \\
\text { LEVTEC } \\
\text { MANOWN } \\
\text { GOVERN } \\
\text { PLANTATION } \\
\text { TECHNOLOGY } \\
\text { CONSTRUCTION } \\
\text { PROPERTIES } \\
\text { COTS PRODUCT } \\
\text { END PRODUCT } \\
\text { PROFITABILITY }\end{array}$ & $\begin{array}{r}.383 \\
.629 \\
-.011 \\
.634 \\
1.152 \\
-.565 \\
.814 \\
.054 \\
.371 \\
.364 \\
.004\end{array}$ & $\begin{array}{l}.072 \\
.170 \\
.004 \\
.282 \\
.407 \\
.460 \\
.327 \\
.285 \\
.247 \\
.210 \\
.003\end{array}$ & $\begin{array}{r}.354 \\
.219 \\
-.180 \\
.141 \\
.160 \\
-.068 \\
.142 \\
.011 \\
.098 \\
.120 \\
.097\end{array}$ & $\begin{array}{r}5.360 \\
3.706 \\
-2.953 \\
2.247 \\
2.829 \\
-1.229 \\
2.490 \\
.189 \\
1.503 \\
1.737 \\
1.675\end{array}$ & $\begin{array}{l}.000 \\
.000 \\
.004 \\
.026 \\
.005 \\
.221 \\
.014 \\
.851 \\
.135 \\
.084 \\
.096\end{array}$ & $\begin{array}{r}.584 \\
.409 \\
-.400 \\
.435 \\
.283 \\
-.093 \\
.098 \\
-.044 \\
-.042 \\
-.122 \\
.329\end{array}$ & $\begin{array}{l}.370 \\
.266 \\
-.214 \\
.165 \\
.206 \\
-.091 \\
.182 \\
.014 \\
.111 \\
.128 \\
.124\end{array}$ & $\begin{array}{r}.280 \\
.193 \\
-.154 \\
.117 \\
.148 \\
-.064 \\
.130 \\
.010 \\
.078 \\
.091 \\
.087\end{array}$ \\
\hline $\begin{array}{l}\text { Constant } \\
\text { Durbin Watson } \\
\text { ANOVA } \\
\text { Std.Error } \\
\text { F Value } \\
\text { Sig. F } \\
\text { R Square } \\
\text { Adjust R Square }\end{array}$ & $\begin{array}{r}2.154 \\
0.000 \\
1.03899 \\
16.951 \\
.000 \\
.507 \\
.477\end{array}$ & & & & & & & \\
\hline
\end{tabular}

\subsubsection{Government Ownership}

Table 4 shows a significant positive association between government ownership and Internet environmental disclosure; the $\mathrm{t}$-value $(\mathrm{t}=2.247, \mathrm{P}<0.05)$ indicates that Government-linked Companies are more concerned about the environment and disclosing more information than non-GLCs. Hence, the alternative hypothesis cannot be rejected. This result is also consistent with the findings of previous studies (Amran \& Devi, 2008). The result supports the legitimacy theory, as it confirms government efforts to create a favourable image in the minds of users over time.

\subsection{Company Characteristics}

Company characteristics constitute the second group of independent variables, and consist of four variables - company size, level of technology, type of industry and profitability.

\subsubsection{Company Size}

Table 4 shows a significant positive association between the size of the company and Internet environmental disclosure. The $t$-value $(t=5.360, P<0.001)$ indicates that firm size is a proxy for Internet voluntary disclosure. Hence, the alternative hypothesis cannot be rejected. The result is consistent with most previous studies (Akrout \& Othman, 2013; Healy \& Palepu, 2001), and supports the legitimacy theory, as large companies always intend to show their operational quality to build and maintain a better public image. 


\subsubsection{Level of Technology}

Table 4 shows a significant positive association between the level of technology and Internet environmental disclosure. The $t$-value $(t=3.706, P<0.001)$ indicates that if a company has the adequate technological equipment, it will increase the level of voluntary disclosure on the Internet. Hence, the alternative hypothesis cannot be rejected. Similar results were found by Adams and Frost (2008), and Joshi and Al-Modhahki (2003). The results also support the legitimacy theory since companies with an IT department intend to take greater advantage of Internet technology and show their concern about the environment.

\subsubsection{Type of Industry}

Table 4 shows that there is a relationship between Internet Environmental Disclosure and the industry. Plantation companies have a significant positive association with Internet Environmental Disclosure $(\mathrm{t}=2.829, \mathrm{P}=0.05)$ as do construction companies $(\mathrm{t}=2.490, \mathrm{P}<$ 0.05). These types of the company increase the level of environmental disclosure for different reasons; construction companies are under the eyes of the public and the government, as their activities harm the environment. However, plantation companies disclose environmental information as it is part of their activities and performance. Hence, the alternative hypothesis cannot be rejected. This result supports the results of previous studies (Suttipun \& Stanton, 2012; Teoh et al., 2003), as well as the legitimacy theory.

\subsubsection{Profitability}

The results show that there is a positive but not significant relationship between profitability and Internet Environmental Disclosure $(\mathrm{t}=1.675, \mathrm{P}<0.10)$. This result indicates that environmental activities and disclosure are not directly connected with profit because companies use environmental activities to establish legitimacy as a long time strategic plan. Hence, the alternative hypothesis cannot be rejected; a similar result was found by Mamat et al. (2013). In short, the results support all the hypotheses except Management ownership, which has a negative association with IED. However, the results support previous studies (Eng \& Mak, 2003; Ghazali, 2007).

\section{LIMITATIONS AND SUGGESTIONS FOR FURTHER RESEARCH}

This paper focuses on the determinants of the environmental disclosure on the Internet by companies in Malaysia, one of the limitations of this study is the period of study, which is only one year (2006); future research may expand the period of study. Future studies could make a comparison between the determinants of IED among developing and developed countries, as it is expected that this comparison is important to determine whether the factors are the same among different cultures and nations. Other future studies may expand this study and examine additional factors that are expected to impact on IED, such as organisational culture and organisational strategy.

\section{CONCLUSION AND MANAGERIAL IMPLICATIONS}

This study examines the impact of ownership structure and companies' characteristics on the level of IED amongst Malaysian companies. Six variables have been used to empirically examine their relationship with IED. These variables are management ownership, government ownership, firm size, level of technology, industry type, and profitability. Multiple regression analysis is used to examine the data collected from the websites of 193 companies. 
The results indicate that government ownership, firm size and level of technology are positively and significantly associated with IED, industry type is significantly associated with the level of IED, management ownership is negatively and significantly associated with IED, and profitability shows a positive but not significant relationship. The results support the legitimacy theory by confirming that companies, in general, attempt to legitimise their operations by providing information that builds a good image regarding social interests and in the minds of external users about the companies.

In this context, companies use the Internet as a means to disclose their environmental reporting, which is considered to be a communication source to investors, social interests and other external users. This paper contributes regarding determining the factors associated with environmental disclosure on the Internet by companies in Malaysia. It is essential to know these factors because IED is still voluntary and in the early stages, and any significant factor can be used by regulators to enhance the level of IED, and, therefore, the level of transparency of companies listed in Malaysia.

\section{REFERENCES}

Abdullah, S.N., \& Mohd-Nasir, N. (2004). Accrual management and the roles of the board of directors and audit committees among Malaysian listed companies: Evidence during the Asian financial crisis. IIUM Journal of Management and Economics, 12(1), 49-80.

Abu Sufian. M., \& Zahan M. (2013) Ownership Structure and Corporate Social Responsibility Disclosure in Bangladesh. International Journal of Economics and Financial Issues, 3 (4), 901 909.

Adams, C. A., \& Frost, G. (2008). Integrating sustainability reporting into management practices. Accounting Forum, 32(4), 288-302

Adham, K. A., \& Ahmed, M. (2005). Adoption of web site and e-commerce technology among Malaysian public companies. Industrial Management \& Data Systems, 9(105), 1172-1187.

Ahmad, Z., Hassan, S., \& Mohammad J. (2003). Determinants of Environmental Reporting in Malaysia. International Journal of Business Studies, 1(11), 69-81.

Akrout, M. M., \& Othman, H. (2013) A Study of the Determinants of Corporate Environmental Disclosure in MENA Emerging Markets. Journal of Reviews on Global Economics, No 2, 4659

Al_arussi, A. S., Selamat M. H., \& Hanifah, H. M. (2013). The association between environmental disclosure and financial disclosure on the Internet by Malaysian listed companies. International Journal of Critical Accounting, 5(2), 156-172.

Al_arussi, A. S., Selamat, M. H., \& Hanifah, H. M. (2009). Determinants of financial and environmental disclosure on the Internet by Malaysian listed companies. Asian Review of Accounting, 17(1), 59 - 76.

Al-Tuwaijri, S., Christensen, T. E., \& Hughes. K. E. (2003). The relations among environmental disclosure, environmental performance, and economic performance: a simultaneous equations approach: King Fahd University of Petroleum and Minerals.

Amran, A., \& Devi, S. S. (2008). The impact of government and foreign affiliate influence on corporate social reporting: The case of Malaysia. Managerial Auditing Journal, 23(4), 386-404.

Andrew, J. (2003). Corporate Governance, the Environment, and the Internet. Electronic Green Journal, 19.

Angskun, J., \& Angskun, T., (2008). Online Trip Planners for the Tourism Industry. Suranaree Journal of Social and Science, 2(1), 33-45.

Arena, C., Bozzolan, S. \& Michelon, G. (2014). Environmental Reporting: Transparency to Stakeholders or Stakeholder Manipulation? An Analysis of Disclosure Tone and the Role of the Board of Directors. Corporate Social Responsibility and Environmental Management, 21(6), 346-361

Banerjee, S. B., (2002). Corporate environmentalism: the construct and its measurement. Journal of Business Research, 55(3),177-191.

Botosan, C. A. (1997). Disclosure level and the cost of equity capital. Journal of Finance 
46(4),1325-1359.

Branco, M., \& Rodrigues, L. (2008). Factors Influencing Social Responsibility Disclosure by Portuguese Companies, Springer Science \& Business Media B.V, (83), 685-701.

Camfferman, K., \& Cooke.T. E. (2002). An analysis of disclosure in the annual reports of the UK and Dutch companies. Journal of International Accounting Research, 1(1), 3-30.

Carney, R. W., \& Child, T. B. (2013). Changes to the Ownership and Control of East Asian Corporations between 1996 and 2008: The primacy of Politics. Journal of Financial Economics, (107), 494-513.

Chambers, E., Chapple, W., Moon, J., \& Sullivan, M. (2003), CSR in Asia: a seven-country study of CSR website reporting, Business and Society. 44(4) : 415-441.

Cheah, C. Y. J., Kang, J., \& Chew, D. A. S. (2007). Strategic analysis of large local construction firms in China. Construction Management and Economics, 25 (1), 25-38.

Cheng, E. C. M., \& Courtenay, S. M. (2006). Board composition, regulatory regime and voluntary disclosure. International Journal of Accounting, 41(3), 262-289.

Claessens, S., Djankov, S., \& Lang, L. H. P. (2000). The separation of ownership and control in East Asian corporations. Journal of Financial Economics, 58, 81-112.

Cooke, T. E. (1992). The Impact of Size, Stock market Listing and Industry Type of a Disclosure in the Annual Report of Japanese Listed Corporations. Accounting and Business Research, 87 (4), 221-237.

Cormier, D., \& Gordon, I. M. (2001). An Examination of Social and Environmental Reporting Strategies, Accounting, Auditing, and Accountability Journal, 14, (5), 587-616.

Craven, B. M., \& Marston, C. L. (1999). Financial reporting on the Internet by leading UK companies. The European Accounting Review, 8(2), 321-333.

Deegan, C., \& Gordon, B. (1996). A Study of the Environmental Disclosure Practices of Australian Corporations. Accounting and Business Research, 3(26), 187-199.

Dhaliwal, D. S., Li, O. Z., Tsang, A., \& Yang, Y. G. (2011). Voluntary nonfinancial disclosure and the cost of equity capital: The initiation of corporate social responsibility reporting. The Accounting Review, 86(1), 59-100.

Dowling, J., \& Pfeffer, J. (1975). Organisational legitimacy: social values and organizational behaviour, Pacific Sociological Review, 18(1), 122-36.

Dunlap, R. E., \& Scarce., R. (1991). Poll Trends: Environmental Problems and Protection. Public Opinion Quarterly, 55 (4), 651-672.

Eccles, R. G., \& Krzus, M. P. (2010). One Report: Integrated Reporting for a Sustainable Strategy. New York: John Wiley \& Sons, Inc.

Eng, L. L., \& Mak, Y. T. (2003). Corporate governance and voluntary disclosure. Journal of Accounting and Public Policy, 22(4), 325-345.

Epstein J., \& Freedman M., (1994). Social disclosure and the individual investor. Accounting, Auditing and Accountability Journal, 7 (4), 94-109.

Frank, D. J., Hironaka, A., \& Schofer, E. (2000). The nation-state and the natural environment over the twentieth century. American Sociological Review, 96-116.

Greenwood, R., \& Hinings, C.R. (1996). Understanding radical organisational change: bringing together the old and the new institutionalism, Academy of Management Review, 21(4),10221054.

GRI 3.1. (2011) Sustainability reporting guidelines. Global Reporting Initiatives TM.

Gul, F. A., \& Leung, S. (2004). Board leadership, outside directors' expertise and voluntary corporate disclosures. Journal of accounting and Policy, 23(5), 351-379.

Guthrie, J. E., \& Mathews, M. R. (1985). Corporate Social Accounting in Australasia. Research in Corporate Social Performance and Policy, 3(7), 251-328.

Halme, M., \& Huse, M. (1997). The Influence of Corporate Governance, Industry and Country Factors on Environmental Reporting. Scandinavian Journal of Management, 13(2), 137-157.

Hassan, A., Jaffer, N., \& Johi, S. K. (1999). Financial Reporting on the Internet By Malaysian Companies: Perceptions and Practices. Asia-Pacific Journal of Accounting, 6 (2), 299-319.

Hassan, N., Yusoff, H.. \& Yatim, N. (2012). Disclosing social responsibility information via the Internet: A study on companies in Malaysia, International Journal of Arts and Commerce, 1(10), 83-96.

Healy, P. M., \& Palepu, K. G. (2001). Information asymmetry, corporate disclosure, and the capital 
markets: A review of the empirical disclosure literature. Journal of Accounting and Economics, 31(1-3), 405-440.

Ho, S. S. M., \& Shun Wong, K. (2001). A study of the relationship between corporate governance structures and the extent of voluntary disclosure. Journal of International Accounting, Auditing and Taxation, 10(2), 139-156.

Homayoun, S., Abdulrahman, R., Johansson, J. \& Malmstrom, M. (2012). Internet corporate social responsibility disclosure among Malaysian listed companies', Bioinfo Financial Management, 2(1), 42-50.

Hossain, M., \& Reaz, M. (2007). The determinants and characteristics of voluntary disclosure by Indian banking companies. Corporate Social Responsibility and Environmental Management, 14(5), 274-288.

Inchausti, A. G. (1997). The influence of company characteristics and accounting regulation on information disclosed by Spanish firms. European Accounting Review, 6(1), 45-68.

Jensen, M. C. (1993). The Modern Industrial Revolution, Exit, and the Failure of Internal Control Systems. The Journal of Finance, 48(3), 831-880.

Jones, T., \& Wicks, A. (1999). Convergent Stakeholder theory, Academy of Management Review, $24,(2), 208-221$

Joshi, P. L., \& Al-Modhahki, J. (2003). Financial reporting on the internet: Empirical evidence from Bahrain and Kuwait. Asian Review of Accounting, 11(1), 88-101.

$\mathrm{Ku}$ Nor Izah Ku Ismail. (2003). The usefulness of Quarterly financial reporting in Malaysia. Unpublished PhD. Thesis, Cardiff University.

Laswad, F., Fisher, R., \& Oyelere, P. (2005). Determinants of voluntary Internet financial reporting by local government authorities. Journal of Accounting and Public Policy, 24(2), 101-121.

Leung, Q. W. Y., Morris, R. D., \& Gray, S. J. (2006). Corporate Transparency In China: Factors influencing Financial Disclosure levels. In 29th Annual Congress of the European.

Lindblom, C. K. (1994). The implications of organisational legitimacy for corporate social performance and disclosure, Critical Perspectives on Accounting Conference. New York.

Lo, K. (2003). Economic consequences of regulated changes in disclosure: the case of executive compensation, Journal of Accounting and Economics, 35(3), 285-314.

Lodhai, S. K. (2004). Corporate Environmental Reporting Media: A Case for the World Wide Web. Electronic Green Journal, 1(20).

Lymer, A. (1997). Corporate Reporting via the Internet - a survey of current usage in the UK and discussion of issues. In First Financial Reporting and Business Communication Conference, Cardiff.

Magness, V. (2006). Strategic posture, financial performance and environmental disclosure: an empirical test of legitimacy theory, Accounting, Auditing and Accountability Journal, 19(4), 540-563.

Mak, Y. T., \& Li, Y. (2001). Determinants of corporate ownership and board structure: evidence from Singapore. Journal of Corporate Finance, 7(3), 235-256.

Mamat, N. H, Abdul Aziz, A., \& Tajudin, A (2013). Internet Reporting by Malaysian Statutory Bodies: An Analysis of Disclosure Practices, Malaysian Journal of Research, 1(1), 1-9

Milne, M. J., \& Adler, R. W. (1999). Exploring the reliability of social and environmental disclosures content analysis. Accounting, Auditing \& Accountability Journal, 12(2), 237-256.

Mohd Ghazali, N. A. (2007). Ownership structure and corporate social responsibility disclosure: some Malaysian evidence. Corporate Governance: The international journal of business in society, 7(3), 251-266.

Mohd Ghazali, N. A., \& Weetman, P. (2006). Perpetuating traditional influences: Voluntary disclosure in Malaysia following the economic crisis. Journal of International Accounting, Auditing and Taxation, 15, 226-248.

Mokhtar, N., \& Sulaiman M. (2012) Environmental Reporting Practices of Malaysian Government Linked Companies (GLCs), International Journal of Economics and Management, 6(2), 241277.

Nagar, V., Nanda, D., \& Wysocki, P. (2003). Discretionary Disclosure and Stock-Based Incentives. Journal of Accounting and Economics 34, 283-309. 
Nik Ahmad, N. N., \& Mohamad, N. A. (2014). Environmental disclosures by the Malaysian construction sector: Exploring extent and quality. Corporate Social Responsibility and Environmental Management, 21(4), 240-252.

Nik Ahmad, N. N., \& Sulaiman, M. (2004). Environmental disclosure in Malaysian Annual Reports: A legitimacy Theory Perspective. International Journal of Commerce \& Management, 14(1), 44-58.

Patten, D. M., \& Trompeter, G. (2003). Corporate responses to political costs: an examination of the relationship between environmental disclosure and earnings management. Journal of Accounting and Public Policy, 22(1), 83-94.

Rahul, H. (2010). Corporate social responsibility- an Indian perspective. Advances in Management $3(6), 42-44$.

Rettab, B., Brik, A. B. \& Mellahi, K. (2009). A study of management perceptions of the impact of corporate social responsibility on organisational performance in emerging economies: The case of Dubai. Journal of Business Ethics 89 (3), 371-390.

Ruland, W., Tung, S., \& George, N. E. (1990). Factors Associated with the Disclosure of Managers' Forecasts. The Accounting Review, 65(3), 710-721.

Salomone. R., \& Galluccio. G. (2001). Environmental Issues and Financial Reporting Trends A Survey in the Chemical and Oil \& Gas Industries, MGMT: the Corporate Sustainable Management University of Messina, Faculty of Economics.

Sekaran, U. (2000). Research methods for business. A skill-building approach, (3rd ed.)

Smith, M., Yahya, K., \& Marzuki Amiruddin, A. (2007). Environmental disclosure and performance reporting in Malaysia. Asian Review of Accounting, 15(2), 185-199.

Solomon, A. \& L. Linda (2002). Incentives and disincentives for corporate environmental disclosure. Business Strategy \& the Environment, 11( 3), 154-169.

Sulaiman, M., Abdullah, N. \& Fatima, A.H., (2014) Determinants of Environmental Reporting Quality in Malaysia, International Journal of Economics, Management and Accounting, 2(1), 63-90

Suttipun, M. \& Stanton, P. (2012) A Study of Environmental Disclosures by Thai Listed Companies on Web sites, Procedia Economics and Finance, 2, 9-15

Tagesson, T., Blank, V., Broberg, P., \& Collin, S., (2009) What Explains the Extent and Content of Social and Environmental Disclosures on Corporate Websites: A Study of Social and Environmental Reporting in Swedish Listed Corporations, Corporate Social - Responsibility and Environmental Management, 16(6), 352.

Tariq, H. I. (2001). An empirical investigation of factors influencing voluntary disclosure of financial information on the Internet in the GCC Countries. Qatar University.

Teoh H. Y., Pin F. W., Joo T. T., \& Ling Y. Y. (2003). Environmental Disclosures-Financial Performance Link: Further Evidence From Industrialising Economy Perspective: Nanyang Technological University, Singapore.

Teoh, H. Y., \& Thong, G. (1984). Another look at corporate social responsibility and reporting: an empirical study in a developing country. Accounting, Organizations and Society, 9(2), 189 206.

Thompson, P., \& Zakaria, Z. (2004). Corporate social responsibility reporting in Malaysia progress and prospects. Journal of Corporate Citizenship (13), 125-136.

Uwuigbe (2011) An Examination of the Relationship between Management Ownership and Corporate Social Responsibility Disclosure: A Study of Selected Firms in Nigeria. Research Journal of Finance and Accounting, 2(6),23

Walden, W. D., \& Schwartz, B. N. (1997). Environmental Disclosures and Public Policy Pressure. Journal of Accounting and Public Policy, 16(2), 125-154.

Wan Mohamad, W. I. A., \& Sulong, Z (2010) Corporate Governance Mechanisms and Extent of Disclosure: Evidence from Listed Companies in Malaysia, International Business Research, 3(4), 216-228.

Watts, R. L., \& Zimmerman, J. L. (1986). Positive Accounting Theory. Englewood Cliffs, New Jersey. Prentice-Hall, Inc, p. 388, chap. 1-3; 12-14.

Xiao, J. Z., Jones, M. J., \& Lymer, A. (2005). A Conceptual Framework for Investigating the Impact of the Internet on Corporate Financial Reporting, The International Journal of Digital Accounting Research, 5(10),131-169 
Yearley, S. (1996). Sociology, Environmentalism, Globalization: Reinventing the Globe. London: Sage.

Zheng, J., Gou, H. T., Li, B., \& Wang, W. (2009). The influence of Financial Factors on Environmental Information Disclosure in China Chemical industry. Xian Jiaotong University, PRC, Working paper.

\section{APPENDIX 1: INTERNET ENVIRONMENTAL DISCLOSURE INDEX}

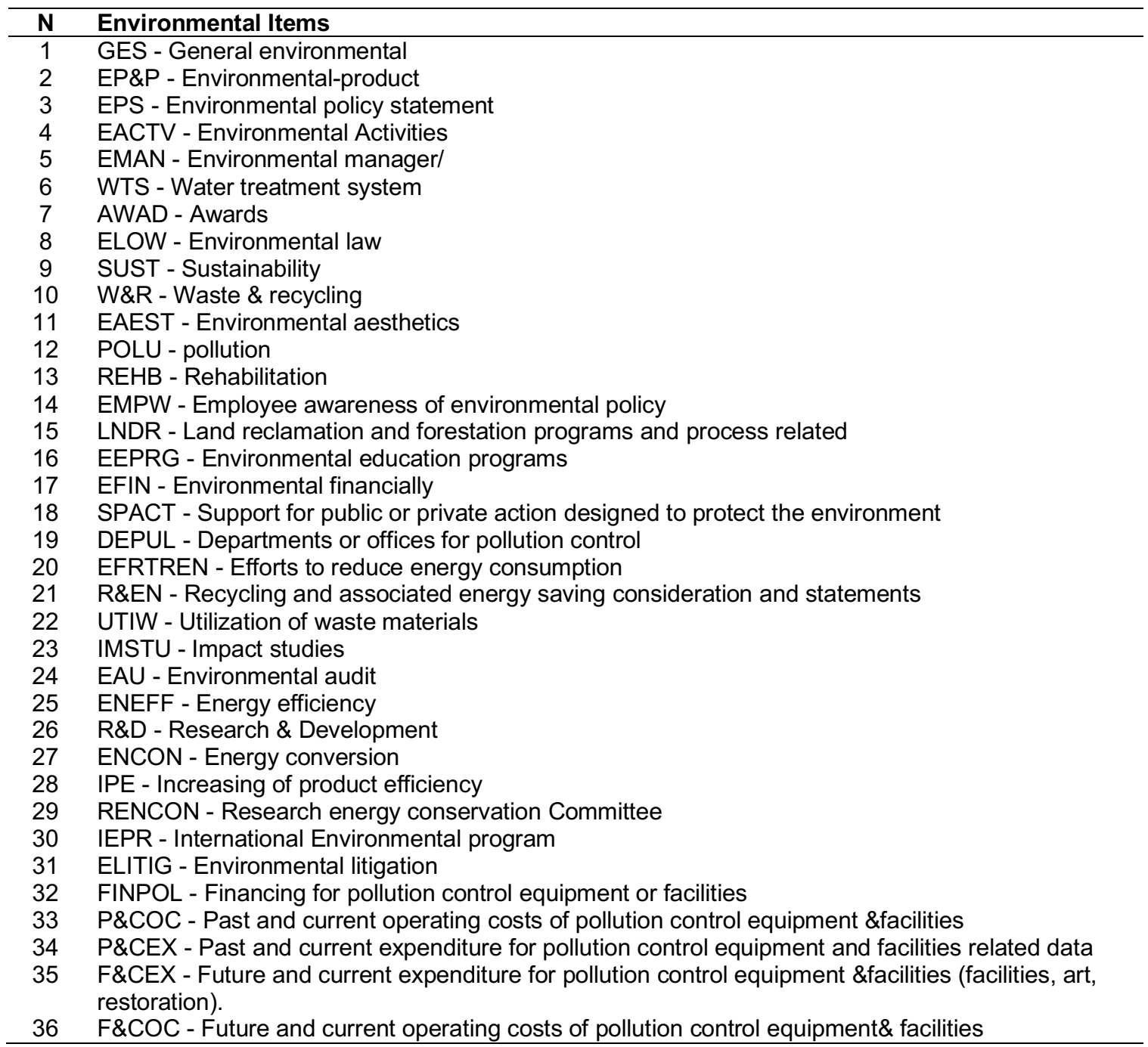

